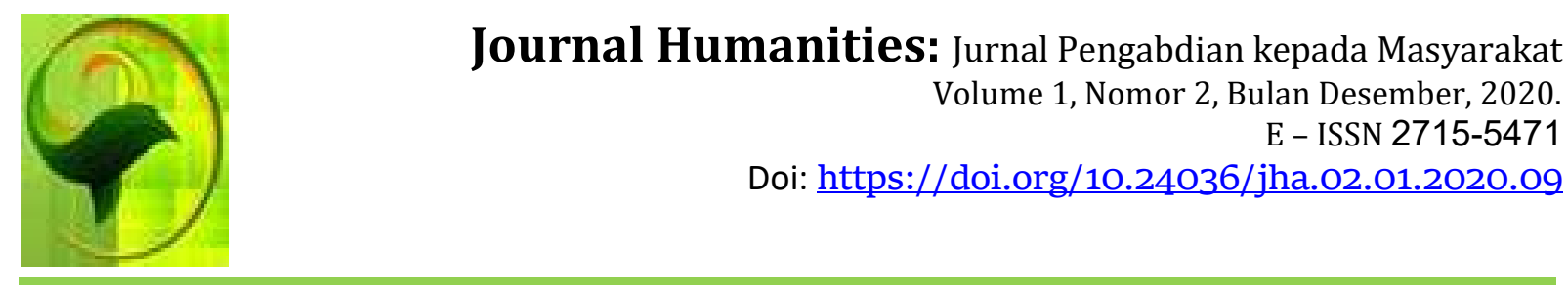

\title{
Socialization Of Cricket To Physical Education Students University Of Bengkulu
}

\author{
${ }^{1}$ Yahya Eko Nopiyanto, ${ }^{2}$ Defliyanto, ${ }^{3}$ Septian Raibowo, ${ }^{4}$ Bogy Restu Ilahi \\ 1,2,3,4 Program Studi Pendidikan Jasmani, Universitas Bengkulu \\ Email: yahyaekonopiyanto@unib.ac.id \\ Diterima: ;Revisi: ;Disetujui
}

\begin{abstract}
The purpose of the socialization of cricket was increased the knowledge of physical education students about the development of cricket in Indonesia and improved the skills of physical education students in playing cricket. The socialization activity was carried out in the physical education study program, University of Bengkulu. Partners in this activity were second semester physical education students, totaling 35 students. This activity was carried out on March 14-15 2020. The forms of activities carried out were socialization and practicum. This activity was carried out with a model of small group discussion, lectures and demonstrations. The stages carried out in this activity consist of three stages, namely: socialization, practicum, and evaluation. Based on the results of the activities and the results of the evaluation, it can be concluded that the socialization of cricket to physical education students increased knowledge about cricket and skills in playing cricket.
\end{abstract}

Keywords: Cricket, Physical, Education, Students, Socialization

\begin{abstract}
Abstrak
Tujuan dari sosialisasi cricket adalah untuk meningkatkan pengetahuan mahasiswa penjas tentang perkembangan cricket di Indonesia dan meningkatkan keterampilan mahasiswa penjas dalam bermain cricket. Kegiatan sosialisasi dilaksanakan di program studi pendidikan jasmani Universitas Bengkulu. Mitra dalam kegiatan ini adalah mahasiswa pendidikan jasmani semester dua yang berjumlah 35 siswa. Kegiatan ini dilaksanakan pada 14-15 Maret 2020. Bentuk kegiatan yang dilaksanakan adalah sosialisasi dan praktikum. Kegiatan ini dilakukan dengan model diskusi kelompok kecil, ceramah dan demonstrasi. Tahapan yang dilakukan dalam kegiatan ini terdiri dari tiga tahapan yaitu: sosialisasi, praktikum, dan evaluasi. Berdasarkan hasil kegiatan dan hasil evaluasi dapat disimpulkan bahwa sosialisasi cricket kepada mahasiswa penjas dapat meningkatkan pengetahuan tentang cricket dan keterampilan dalam bermain cricket.
\end{abstract}

Keywords: Criket, Pendidikan, Jasmani, Mahasiswa, Sosialisasi

\section{ANALISIS SITUASI}

Program studi pendidikan jasmani merupakan salah satu program studi favorit di Universitas Bengkulu yang mempunyai visi menghasilkan tenaga pendidikan jasmani olahraga dan kesehatan yang unggul dan KREATIF (Kerja Keras, Religius, Empati, Akuntabel, Tangguh, Inovatif dan Profesional) bertaraf internasional pada tahun 2025. Untuk dapat menghasilkan tenaga pendidikan jasmani olahraga dan kesehatan yang unggul maka mahasiswa pendidikan jasmani harus dibekali dengan berbagai macam keterampilan dan pengetahuan. Berdasarkan hasil penelitian dapat diketahui bahwa pengetahuan mempunyai hubungan yang signifikan dengan kemampuan mengajar yang kreatif (Gunawan \& Heracwati, 2016).. Selain itu terdapat hubungan yang positif antara keterampilan dengan prestasi belajar (Nasution, 2016). Artinya, supaya mahasiswa pendidikan jasmani mampu menjadi pendidik yang kreatif maka dibutuhkan pengetahuan dan keterampilan yang cukup mengenai bidang ilmu yang dipelajarinya.

Salah satu pengetahuan olahraga yang harus dimiliki oleh mahasiswa pendidikan jasmani adalah pengetahuan mengenai olahraga cricket. Olahraga cricket dimainkan oleh 11 orang dalam satu tim, dan lamanya permaianan tidak dibatasi oleh waktu tetapi menggunakan perpindahan (over). Olahraga cricket merupakan salah satu cabang olahraga yang dimainkan di lapangan rumput yang 
mengarah pada pengembangan mental yang postif dan mengutamakan kejujuran, keadilan, kehormatan, menerima keputusan wasit, sopan dan mengendalikan diri. Aturan-aturan ini yang ditanamkan dalam setiap jiwa pemain cricket. Selain itu olahraga cricket berorientasi kepuasan pribadi, pencapaian prestasi dan pengembangan prestasi. Pada pertandingan internasional di Perth tahun 2000, Indonesia memperoleh juara 3 dengan mengalahkan Korea Selatan (Persatuan Cricket Indonesia, 2019).

Berdasarkan pada uraian tersebut, dapat diketahui bahwa olahraga cricket merupakan sarana olahraga yang mampu mengembangkan mahasiwa pendidikan jasmani menjadi pribadi yang jujur, adil, menghormati, taat aturan, sopan, mampu mengendalikan diri, dan menjadi pribadi yang berprestasi akademik dan olahraga. Namun, di prodi pendidikan jasmani, olahraga cricket belum masuk dalam kurikulum pembelajaran dan tidak termasuk dalam kegiatan ekstrakurikuler. Padahal, saat ini mahasiswa pendidikan jasmani sangat membutuhkan banyak pengetahuan tentang perkembangan olahraga cricket di Indonesia. Selain itu, olahraga cricket adalah salah satu olahraga yang dapat menjadi sarana bagi mahasiswa pendidikan jasmani yang ingin berprestasi di bidang olahraga karena masih mempunyai peluang yang sangat besar.

Dengan demikian, maka perlu dilakukan sosialisasi olahraga cricket untuk meningkatkan pengetahuan olahraga bagi mahasiswa pendidikan jasmani Universitas Bengkulu. Tujuan dari sosialisasi ini adalah untuk meningkatkan pengetahuan mahasiswa pendidikan jasmani tentang perkembangan olahraga cricket di Indonesia dan meningkatkan keterampilan mahasiswa pendidikan jasmani dalam bermain cricket. Manfaat kegiatan ini bagi mahasiswa pendidikan jasmani adalah sebagai memberikan sarana bagi mahasiswa untuk menyalurkan dan mengembangkan potensi dalam bermain cricket dan memberikan peluang kepada mahasiswa untuk menjadi atlet cricket provinsi Bengkulu yang akan bertanding di Pekan Olahraga Mahasiswa tahun 2021 di Provinsi Sumatera Barat, Padang.

\section{SOLUSI DAN TARGET}

Solusi yang dapat diberikan untuk mengatasi permasalahan mahasiswa mengenai kurangnya tingkat pemahaman dan keterampilan dalam bermain cricket maka perlu diadakan sosialisasi olahraga cricket kepada mahasiswa pendidikan jasmani di Universitas Bengkulu. Target dan luaran kegiatan pengabdian adalah meningkatnya pemahaman mahasiswa penjas tentang cricket dan meningkatkan keteranpilan bermain cricket.

\section{METODE PELAKSANAAN}

Kegiatan sosialisasi dilaksanakan di prodi pendidikan jasmani Universitas Bengkulu yang beralamat di Jalan Raden Fatah No 3, Kelurahan Pagar Dewa, Kecamatan Selebar, Kota Bengkulu. Mitra dalam kegiatan ini adalah mahasiswa pendidikan jasmani semester dua, yang berjumlah 35 mahasiswa. Kegiatan ini dilaksanakan pada 14-15 Maret 2020. Bentuk kegiatan yang dilakukan adalah sosialisasi dan praktikum. Kegiatan ini dilakukan dengan model small group discussion, ceramah, dan demonstrasi. Tahapan yang dilakukan pada kegiatan ini terdiri dari tiga tahapan, yaitu:

Tahap pertama adalah sosialisasi yang dilakukan bertujuan untuk mengenalkan olahraga cricket kepada mahasiswa pendidikan jasmani, memberikan pemahaman yang cukup mengenai olahraga criket termasuk di dalamnya membahas tentang sarana prasarana cricket, peraturan permainan dan pertandingan, tugas wasit, dan cara memberikan nilai pada permainan cricket.

Tahap kedua adalah praktikum yang bertujuan untuk memberikan kesempatan kepada peserta kegiatan dalam melakukan teknik dasar bermain cricket, latihan memegang alat cricket, serta latihan bermain cricket.

Tahap ketiga adalah evaluasi yang dilaksanakan untuk mengevaluasi kegiatan ini. Evaluasi dilaksanakan dengan menggunakan data angket yang diberikan kepada mahasiswa pada awal mengikuti kegiatan ini dan angket yang diberikan pada akhir kegiatan ini. Evaluasi dilakukan dengan membandingkan nilai peserta sebelum dan sesudah kegiatan dilaksanakan.

\section{PELAKSANAAN KEGIATAN Sosialisasi}

Langkah awal yang ditempuh oleh tim pengabdi untuk dapat melaksanakan kegiatan sosialisasi adalah berdiskusi dengan koordinator prodi pendidikanjasmani untuk mendapatkan 


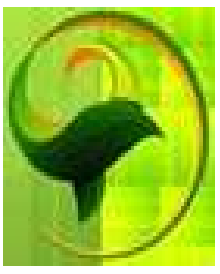

Journal Humanities: Jurnal Pengabdian kepada Masyarakat Volume 1, Nomor 2, Bulan Desember, 2020. E - ISSN 2715-5471

Doi: https://doi.org/10.24036/jha.02.01.2020.09

persetujuan kegiatan ini. Setelah mendapatkan persetujuan maka tim pengabdi melaksanakan kegiatan sosialisasi olahraga cricket kepada mahasiswa pendidikan jasmani Universitas Bengkulu. Kegiatan sosialisasi dilaksanakan pada 14 Maret 2020 yang diikuti oleh 35 peserta. Tempat pelaksanaan sosialisasi adalah di gedung serbaguna prodi pendidikan jasmani. Materi yang disajikan dibagi menjadi dua sesi. Pada sesi pertama sosialisasi adalah pengenalan olahraga cricket yang terdiri dari sejarah olahraga cricket di Indonesia, peralatan yang dibutuhkan untuk bermain cricket, bentuk dan ukuran lapangan cricket, dan cara bermain cricket. Pada saat materi sosialisasi diberikan sangat terlihat antusias dari para peserta untuk memperhatikan materi yang disajikan. hal ini terlihat dari pertanyaanpertanyaan yang diajukan oleh peserta. Pada awalnya terlihat banyak peserta yang masih asing dengan cricket, belum memahami bagaimana cara bermain cricket. Oleh karena itu, tim pengabdi memberikan materi secara mendasar dan bertahap disertai dengan video dan demonstrasi.

Materi diskusi terdiri dari beberapa pertanyaan, diantaranya adalah apa saja peralatan yang dibutuhkan untuk bermain cricket, bagaimana cara memegang batt, bagaimana cara melempar dan menangkap bola, apa saja istilah-istilah yang ada dalam permainan cricket, dan sebagainya. Masingmasing kelompok diberikan waktu 30 menit untuk berdiskusi dan masing-masing kelompok mempresentasikan hasil diskusinya di depan kelas, sementara anggota kelompok yang lain menanggapi hasil presentasi.

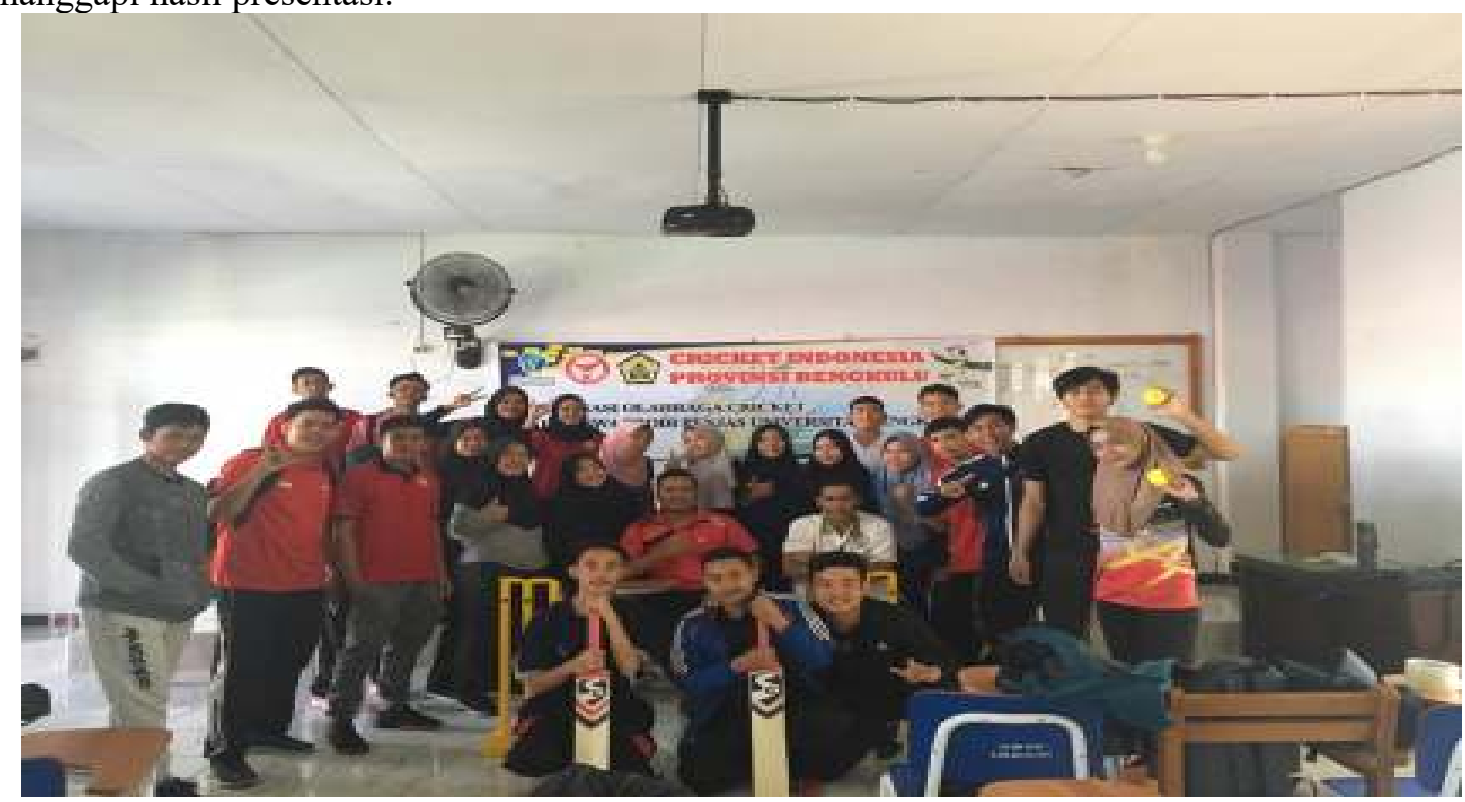

Gambar 1. Foto Bersama Peserta Pada Akhir Sesi Pertama

Pada sesi kedua, materi yang disajikan adalah perwasitan dan skoring dalam permainan cricket. Materi perwasitan yang disajikan meliputi caught, bowled, hit wicket, run out, stumped, leg before wicket serta sinyal-sinyal dari wasit mengenai hal tersebut. Sedangkan materi skoring terdiri dari cara memberikan nilai 1, 4, 6 kepada pemain dan bagaimana cara menuliskannya di lembar score sheet. Materi ini sangat asing bagi mahasiswa dan terlihat pada awal penyampaian mahasiswa masih merasa kesulitan. Tim pengabdi menyajikan materi dengan metode ceramah dan demonstrasi serta menggunakan media berupa video pertandingan lengkap dengan cara perwasitan dan penskoran. 


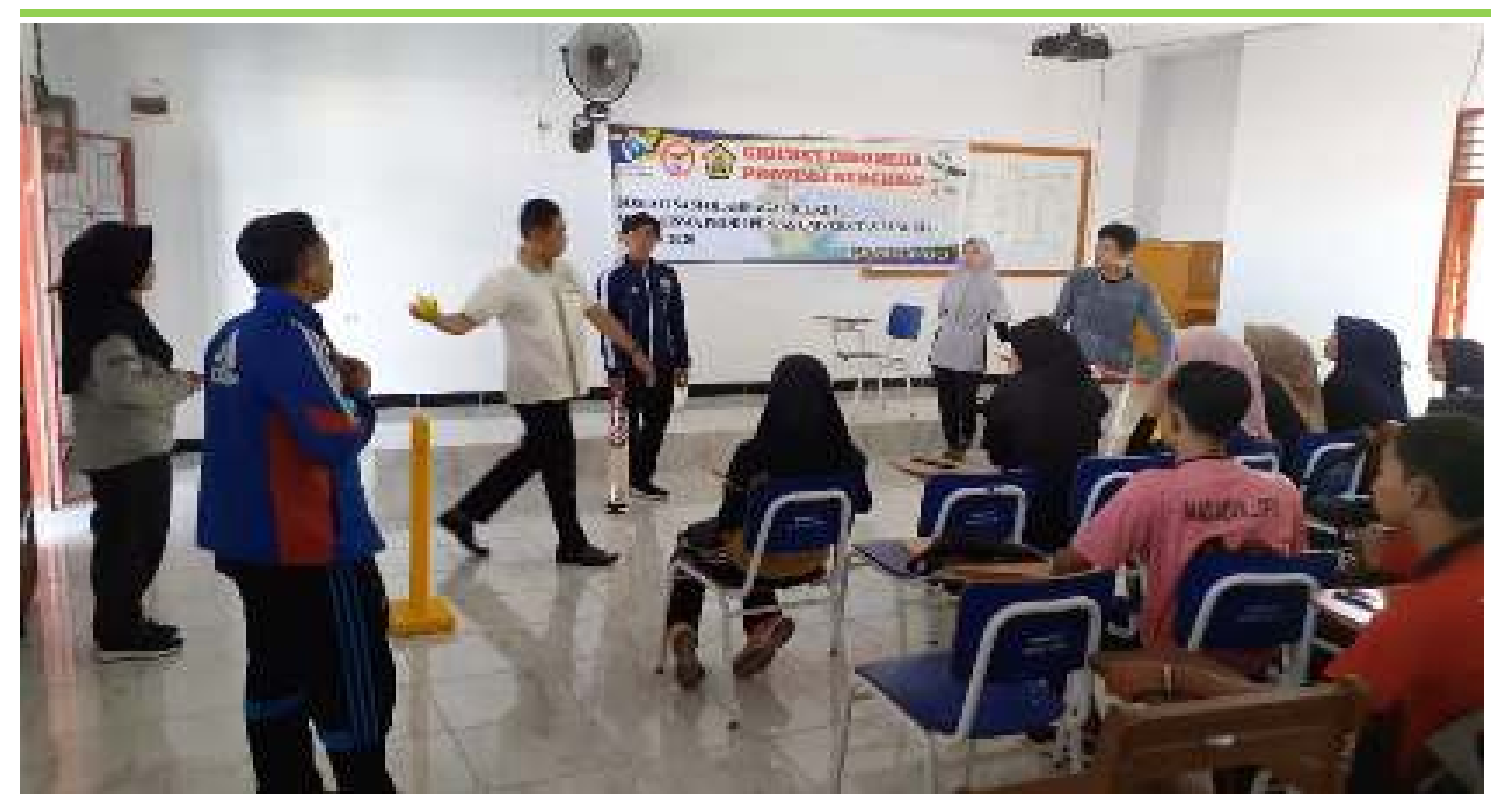

Gambar 2. Penyampaian Materi Perwasitan dan Skoring

\section{Praktikum}

Praktikum adalah kegiatan yang diberikan kepada peserta untuk mempraktikkan teori yang telah diberikan di dalam kelas. Kegiatan praktikum dilaksanakan pada tanggal 15 Maret 2020 di halaman depan prodi pendidikan jasmani. Kegiatan praktikum dilakukan selama 2 jam, dengan metode ceramah dan demonstrasi. Tim pengabdi mengulas kembali materi yang disampaikan di kelas dan mendemontrasikan di depan semua peserta. Setelah tim pengabdi memberikan dan mendemonstrasikan, maka langkah selanjutnya adalah praktikum untuk semua peserta. Pada bagian ini setiap peserta melakukan praktik teknik-teknik dasar bermain cricket seperti, melempar bola, menangkap bola, memukul bola, memegang batt. Peserta melakukan lempar tangkap bola secara berpasangan dari jarak dekat ke jarak yang sesungguhnya. Selain itu juga setiap peserta mempraktikkan secara langsung mengenai caught, bowled, hit wicket, run out, stumped, leg before wicket serta sinyal-sinyal dari wasit dilengkapi dengan penskoran dari setiap kejadian.

Semua peserta sangat antusias untuk melakukan praktik bermain cricket. Menurut mereka olahraga cricket merupakan salah satu olahraga yang mempunyai peluang bagus untuk berkembang di provinsi Bengkulu. Untuk itu mereka meminta kepada tim pengabdi untuk membentuk pengurus olahraga cricket di provinsi Bengkulu sehingga bisa menjadi wadah bagi peserta untuk mengembangkan potensi dirinya dan berprestasi di olahraga cricket. peserta juga meminta supaya olahraga cricket bisa menjadi bagian dari kurikulum pendidikan jasmani di Universitas Bengkulu.

Setelah semua rangkaian kegiatan praktikum selesai. Tim pengabdi memberikan kesempatan kepada peserta untuk bertanya dan berdiskusi mengenai kesulitan dalam bermain cricket. pada akhir kegiatan praktikum, tim pengabdi memberikan motivasi kepada semua peserta untuk dapat berpartisipasi dalam mengenalkan olahraga cricket di provinsi Bengkulu. Dalam mengenalkan olahraga cricket dapat dimulai dari sekolah dasar dengan memodifikasi alat dan permainannya. Karena dengan memodifikasi alat dan permainan dapat meningkatkan minat para pelajar dalam bermain cricket (Mardela, 2019). 


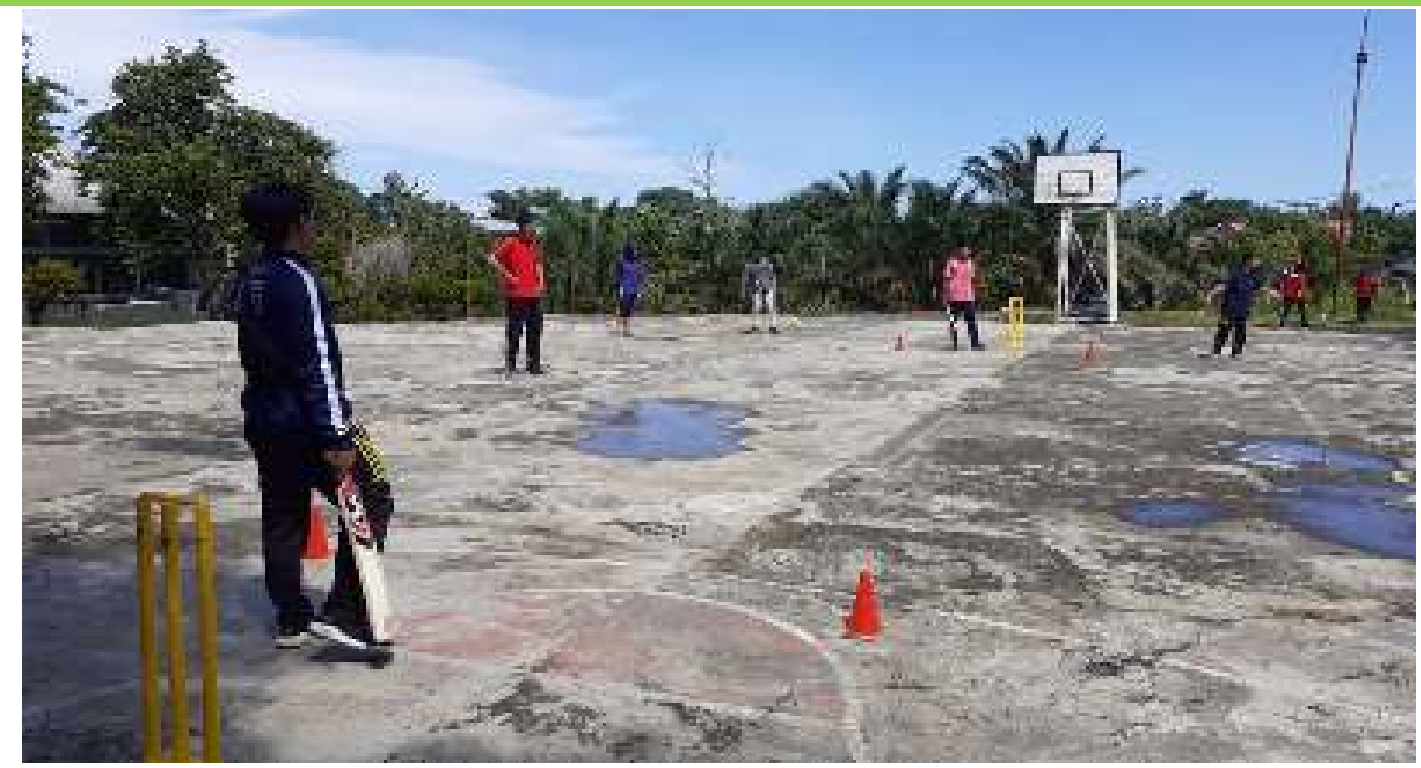

Gambar 3. Kegiatan Praktikum Bagi Peserta

\section{Evaluasi}

Evaluasi merupakan cara untuk mengetahui keberhasilan program yang telah dilaksanakan (Raibowo \& Nopiyanto, 2020). Evaluasi dilakukan untuk mengetahui pengetahuan dan keterampilan mahasiswa pendidikan jasmani dalam bermain cricket. Evaluasi dilakukan dengan cara menganalisis hasil pengamatan dan data dari angket yang diberikan kepada semua peserta kegiatan ini.

\section{HASIL DAN PEMBAHASAN}

Kegiatan ini menghasilkan peningkatan pengetahuan mahasiswa pendidikan jasmani tentang permainan olahraga cricket dan peningkatan keterampilan mahasiswa pendidikan jasmani dalam bermain cricket. Pengetahuan yang diberikan pada kegiatan ini adalah, (1) sejarah cricket di Indonesia, (2) peralatan bermain cricket, (3) lapangan untuk bermain cricket, dan (4) cara bermain cricket. Sedangkan keterampilan yang diberikan pada kegiatan ini adalah, (1) keterampilan memegang batt, (2) keterampilan memukul bola, (3) keterampilan bowling, (4) keterampilan fielding, (5) keterampilan melakukan wicket, (6) keterampilan scoring. Pada akhir kegiatan tim pengabdi melakukan tes keterampilan bermain cricket dan angket untuk membandingkan pengetahuan dan keterampilan peserta antara sebelum dan sesudah kegiatan dilaksanakan. Hasil kegiatan dapat dilihat pada tabel 1 di bawah ini.

Tabel 1 .

Hasil kegiatan

\begin{tabular}{|l|l|l|}
\hline Indikator & \multicolumn{2}{|c|}{ Hasil kegiatan } \\
\hline & Pre-test & Post-test \\
\hline Pengetahuan & $20 \%$ & $70 \%$ \\
\hline Keterampilan & $10 \%$ & $40 \%$ \\
\hline
\end{tabular}

Berdasarkan data hasil evaluasi kegiatan pada tabel 1, dapat diketahui bahwa hasil kegiatan ini memberikan dampak positif yang signifikan terhadap peningkatan pengetahuan mahasiswa pendidikan jasmani mengenai olahraga cricket, dan mampu meningkatkan keterampilan bermain cricket. Pada indikator pengetahuan terdapat peningkatan $50 \%$, artinya ada perbedaan yang signifikan antara sebelum dan setelah diadakan kegiatan. Pada indikator keterampilan terdapat peningkatan 30\%, artinya ada perbedaan yang signifikan antara sebelum dan setelah diadakan kegiatan. Hal ini dapat terjadi karena selama kegiatan berlangsung, tim pengabdi memberikan materi dengan jelas, mudah dipahami, dan dilengkapi dengan video dan demonstrasi. Selain itu juga, semua peserta sangat antusias dan termotivasi dalam mengikuti kegiatan ini. 


\section{Diskusi}

Terjadinya peningkatan pengetahuan yang dialami oleh peserta tidak lepas dari metode sosialisasi yang digunakan oleh tim pengabdi yaitu dengan bantuan video melalui infocus. Penggunaan media infocus mampu menyajikan materi dengan baik (Astuti et al, 2020). Dengan bantuan video yang disajikan sangat membantu peserta dalam memahami materi yang disajikan. metode ceramah juga digunakan oleh tim pengabdi untuk menyampaikan materi kegiatan dan terbukti mampu meningkatkan pengetahuan peserta. Setelah materi disampaikan, tim pengabdi membagi peserta menjadi beberapa kelompok kecil (small group discussion) untuk berdiskusi mengenai materi yang telah diberikan. Tim pengabdi menggunakan metode small group discussion karena telah terbukti efektif dalam pembelajaran dan memudahkan peserta untuk berdiskusi mengenai materi yang disampaikan (Cristiani, 2014; Purwanti, 2017; Nopiyanto \& Raibowo, 2020). Pemberian materi dengan diskusi mampu meningkatkan pengetahuan peserta sosialisasi (Syahputra et al, 2020). Pada akhir sesi sosialisasi dan diskusi, tim pengabdi memberikan motivasi kepada semua peserta untuk dapat ikut berpastisipasi aktif dalam mengenalkan olahraga cricket di provinsi Bengkulu. Peserta lakilaki menunjukkan motivasi dan kepercayaan diri yang lebih baik dibandingakan peserta perempuan (Nopiyanto \& Alimuddin, 2020). Motivasi selalu diberikan di setiap akhir dalam penyampaian materi karena motivasi mampu memberikan kontribusi bagi atlet untuk berprestasi (Nopiyanto \& Dimyati, 2018).

Kegiatan ini juga meningkatkan keterampilan peserta. Peningkatan tersebut dikarenakan dalam kegiatan praktikum tim pengabdi melakukan modifikasi sasaran dan variasi gerakan. Misalkan, dengan menggunakan variasi jarak lemparan dan tangkapan. Dengan modifikasi maka akan mempermudah peserta dalam melakukan gerakan atau teknik yang diajarkan (Pujianto, 2020). Sedangkan pada saat praktik memegang batt dan memukul bola, peserta diajarkan dengan menggunakan metode elementer atau per bagian dan pendekatan teknik. Pendekatan ini terbukti membantu meningkatkan keterampilan bermain (Festiawan, 2020). Metode ini digunakan karena terbukti efektif untuk meningkatkan keterampilan memukul bola (Trishandra, 2018). Berdasarkan hasil kegiatan sebelumnya dapat diketahui bahwa metode demonstrasi dalam kegiatan pengabdian terbukti efektif untuk meningkatkan pengetahuan dan keterampilan peserta kegiatan (Atradinal et al, 2020; Putri et al, 2020; Nopiyanto \& Raibowo, 2020). Setelah melakukan beberapa kali percobaan, peserta melaui menunjukkan kepercayaan diri dalam bermain cricket. Kepercayaan diri yang tinggi merupakan aspek yang sangat dibutuhkan oleh atlet untuk berprestasi di bidang olahraga yang ditekuninya khususnya atlet dari olahraga tim(Nopiyanto, Dimyati, \& Dongoran, 2019).

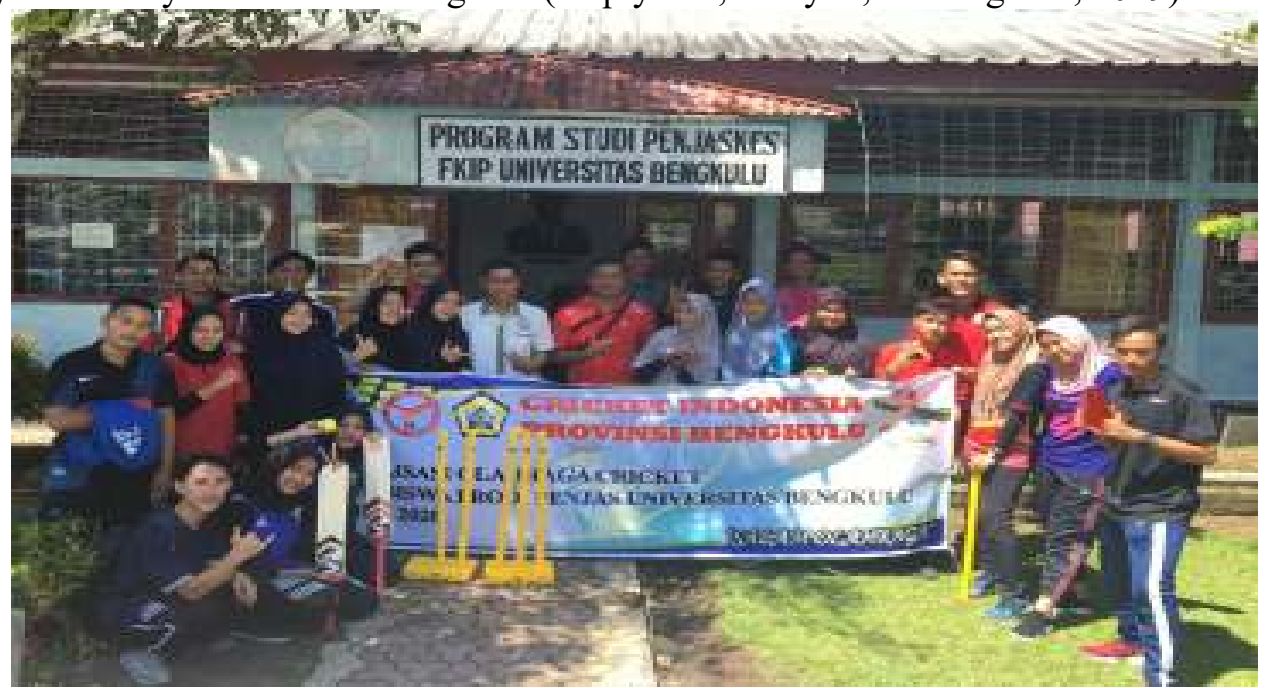

Gambar 4. Foto Bersama Setelah Praktikum dan Evaluasi Kegiatan

\section{KESIMPULAN}

Berdasarkan pada hasil kegiatan dan hasil evaluasi dapat disimpulkan bahwa sosialiasi olahraga cricket pada mahasiswa pendidikan jasmani Universtas Bengkulu mampu meningkatkan pengetahuan tentang olahraga cricket dan keterampilan dalam bermain cricket. Disarankan kepada 
Journal Humanities: Jurnal Pengabdian kepada Masyarakat Volume 1, Nomor 2, Bulan Desember, 2020.

E - ISSN 2715-5471

Doi: https://doi.org/10.24036/jha.02.01.2020.09

mahasiswa penjas untuk terus berlatih meningkatkan keterampilan bermain cricket. Tim pengabdi juga memberikan saran kepada koordinator prodi penjas dan dosen bidang kurikulum untuk memasukkan olahraga cricket dalam mata kuliah pilihan atau ekstrakurikuler prodi penjas Universitas Bengkulu.

\section{PENGAKUAN}

Tim pengabdi mengucapkan terima kasih kepada koordinator prodi pendidikan jasmani Universitas Bengkulu yang telah memberikan izin dan kepada mahasiswa pendidikan jasmani semester dua yang telah bersedia untuk menjadi mitra dalam kegiatan ini.

\section{DAFTAR PUSTAKA}

Arsil, A., Neldi, H., Rosmawati, R., \& Atradinal, A. (2019). Training of Penjasorkes Teachers in Efforts to Increase Extracurricular Activities Basic School Athletics as a Sub-district Padang Utara. Jurnal Humanities Pengabdian Kepada Masyarakat, 1(1), 48-59.

Astuti, Y., Zulbahri, Z., Erianti, E., \& Rosmawati, R. (2020). Pelatihan Metode Interval Ekstensif Terhadap Kemampuan Daya Tahan Aerobik. Jurnal Abdidas, 1(3), 109-118.

Atradinal, A., Syahputra, R., Oktarifaldi, O., Mardela, R., Putri, L. P., Oktavianus, I., ... \& Bakhtiar, S. (2020). Dissemination and Training of Identification and Development of Sport Talent for Physical Education Teachers and Sports Trainers in the Province of West Sumatra. Jurnal Humanities Pengabdian Kepada Masyarakat, 1(1), 112-125.

Christiani, A. (2014). Penerapan metode Small Group Discussion dengan Model Cooperative Learning untuk meningkatkan Hasil Belajar siswa di Sekolah Dasar. Jurnal Penelitian Pendidikan Guru Sekolah Dasar, 2(2), 1-11.

Festiawan, R. (2020). Pendekatan Teknik dan Taktik: Pengaruhnya terhadap Keterampilan Bermain Futsal. Gelanggang Olahraga: Jurnal Pendidikan Jasmani Dan Olahraga, 3(2), 143-155.

Gunawan, S., \& Shieh, C. J. (2016). A study on the effects of knowledge share in virtual community on creative teaching behaviors and teacher efficacy. EURASIA Journal of Mathematics, Science and Technology Education, 12(4), 1101-1113.

Mardela, R., Yendrizal, Y., \& Yudi, A. A. (2019). Modifikasi Permainan Olahraga Kriket Untuk Pemula. Performa Olahraga, 4(02), 206-213.

Nasution, H. F. (2016). Hubungan metode mengajar dosen, keterampilan belajar, sarana belajar dan lingkungan belajar dengan prestasi belajar mahasiswa. Jurnal Ilmu Pendidikan, 8(1).

Nopiyanto, Y. E., \& Dimyati, D. (2018). Karakteristik psikologis atlet Sea Games Indonesia ditinjau dari jenis cabang olahraga dan jenis kelamin. Jurnal Keolahragaan, 6(1), 69-76.

Nopiyanto, Y. E., Dimyati, D., \& Dongoran, F. (2019). Karakteristik Psikologis Atlet Sea Games Indonesia Ditinjau Dari Cabang Olahraga Tim. Sporta Saintika, 4(2), 27-46.

Nopiyanto, Y. E., \& Alimuddin, A. (2020). Are There Difference The Psychological Characteristics Of Indonesian Sea Games Athletes In Terms Of Team Sports Based On Sex?. Sporta Saintika, 5(1), 72-80.

Nopiyanto, Y. E., \& Raibowo, S. (2020). Pelatihan Olahraga Futsal sebagai Sarana Mengurangi Aktivitas Game Online pada Anak-Anak di Kelurahan Mangunharjo. JURPIKAT (Jurnal Pengabdian Kepada Masyarakat), 1(2), 67-77. 
Nopiyanto, Y. E., \& Raibowo, S. (2020). Penerapan model pembelajaran jigsaw untuk meningkatkan motivasi dan hasil belajar mahasiswa penjas pada mata kuliah filsafat penjas dan olahraga. Journal Of Sport Education (JOPE), 2(2), 61-69.

Nopiyanto, Y. E., Raibowo, S., Sugihartono, T., \& Yarmani, Y. (2020). Pola Hidup Sehat Dengan Olahraga dan Asupan Gizi Untuk Meningkatkan Imun Tubuh Menghadapi Covid-19. Dharma Raflesia: Jurnal Ilmiah Pengembangan dan Penerapan IPTEKS, 18(2), 90-100.

Persatuan Cricket Indonesia. (2019). Pengenalan Olahraga Cricket; Pelatihan Wasit dan Scoring. Jakarta: Pengurus Pusat Persatuan Cricket Indonesia.

Pujianto, D., Sutisyana, A., Arwin, A., \& Nopiyanto, Y. E. (2020). Pengembangan Model Latihan Passing Sepakbola Berbasis Sasaran Teman. Journal Coaching Education Sports, 1(1), 1-12.

Purwanti, S. (2017). Penerapan small group discussion untuk meningkatkan hasil belajar dan keaktifan mahasiswa PGSD UAD. DIALEKTIKA Jurnal Pemikiran dan Penelitian Pendidikan Dasar, 7(1), 10-19.

Putri, L. P., Marta, I. A., Oktarifaldi, O., Jonni, J., Yulifri, Y., Kibadra, K., ... \& Bakhtiar, S. (2020). Dissemination and Training of Early Childhood Motion Skill Level Development for PAUD/Kindergarten and Elementary Teachers in Lima Puluh Kota District. Jurnal Humanities Pengabdian Kepada Masyarakat, 1(1), 139-151.

Raibowo, S., \& Nopiyanto, Y. E. (2020). Evaluasi Pembelajaran Pendidikan Jasmani Olahraga \& Kesehatan pada SMP Negeri Se-Kabupaten Mukomuko melalui Pendekatan Model Context, Input, Process \& Product (CIPP). Jurnal Pendidikan Kesehatan Rekreasi, 6(2), 146-165.

Syahputra, R., Bakhtiar, S., Oktarifaldi, O., Rasyid, W., \& Putri, L. P. (2020). Assistance In Learning Basic Early Childhood Motion Skills For Early Childhood Teachers In Pesisir Selatan Regency. Jurnal Humanities Pengabdian Kepada Masyarakat, 1(1), 73-89.

Sudarsono, S. (2020). Perbandingan pengaruh antara latihan bowling jarak sesungguhnya dengan latihan bowling jarak dekat ke jarak sesungguhnya terhadap ketepatan dan kecepatan bowling cricket pada siswa putra ekstrakulikuler cricket. Jorpres (Jurnal Olahraga Prestasi), 16(1), 3544 .

Trishandra, J. (2018). Pengaruh Metode Pembelajaran Global Dan Elementer Terhadap Keterampilan Teknik Batting (Memukul Bola) Atlet Cricket Universitas Negeri Padang. Cerdas Sifa Pendidikan, 1(2), 16-26. 